\title{
Biological performance of the predatory mites Amblyseius largoensis and Euseius concordis fed on eggs of Aleurodicus cocois
}

Author(s): Josiane Pacheco De Alfaia, Maria Edvania Neves Barros, Luana Lima Melo, Debora Barbosa Lima, Nivia Da Silva Dias-Pini \& Jose Wagner Silva Melo

Source: Systematic and Applied Acarology, 23(11):2099-2103.

Published By: Systematic and Applied Acarology Society

URL: http://www.bioone.org/doi/full/10.11158/saa.23.11.2

BioOne (www.bioone.org) is a nonprofit, online aggregation of core research in the biological, ecological, and environmental sciences. BioOne provides a sustainable online platform for over 170 journals and books published by nonprofit societies, associations, museums, institutions, and presses.

Your use of this PDF, the BioOne Web site, and all posted and associated content indicates your acceptance of BioOne's Terms of Use, available at www.bioone.org/page/terms_of_use.

Usage of BioOne content is strictly limited to personal, educational, and non-commercial use. Commercial inquiries or rights and permissions requests should be directed to the individual publisher as copyright holder. 


\title{
Biological performance of the predatory mites Amblyseius largoensis and Euseius concordis fed on eggs of Aleurodicus cocois
}

\author{
JOSIANE PACHECO DE ALFAIA ${ }^{1}$, MARIA EDVANIA NEVES BARROS ${ }^{1}$, LUANA LIMA \\ MELO $^{1}$, DEBORA BARBOSA LIMA ${ }^{2}$, NIVIA DA SILVA DIAS-PINI ${ }^{3} \&$ JOSE WAGNER \\ SILVA MELO ${ }^{1}$ \\ ${ }^{1}$ Departamento de Fitotecnia, Universidade Federal do Ceará, Pici, 60455-760, Fortaleza, CE, Brasil. \\ ${ }^{2}$ Departamento de Agronomia - Entomologia, Universidade Federal Rural de Pernambuco, Av. Dom Manoel de \\ Medeiros s/n, Dois Irmãos, 52171-900 Recife, PE, Brasil. \\ ${ }^{3}$ Entomologia, Embrapa Agroindústria Tropical, 60511-110, Fortaleza, CE, Brazil \\ *Correspondence to: Prof. José Wagner; E-mail: wagnermelo@ufc.br
}

Aleurodicus cocois (Curtis) (Hemiptera: Aleyrodidae) represents one of the main threats to cashew tree crops, Anacardium occidentale L. (Anacardiaceae), in several countries of South America (Martin 1987; Byrne et al. 1990; Evans 2007). This threat is not only represented by direct damage caused by feeding on the plant phloem and secretion of honeydew (Byrne et al. 1990; Byrne \& Bellows 1991) but also by the lack of effective control methods against this pest (Bleicher \& Melo 1996; Melo \& Bleicher 2002; Mesquita \& Braga Sobrinho 2013).

In Brazil, which is one of the largest cashew producers in the world (Pessoa et al. 2015), there are no registered products for the control of $A$. cocois (Agrofit 2018). A potential alternative for the control of $A$. cocois is the use of predatory mites of the family Phytoseiidae as biological control agents. The diversity of predatory mites in cashew trees has been little explored. Some phytoseiid species have been reported on cashew trees (Lima \& Gondim Jr 2008; Monteiro et al. 2017). A recent study reported that the phytoseiid mites Amblyseius largoensis (Muma) and Euseius concordis (Chant) are potential natural enemies for controlling A. cocois (de Alfaia et al. 2018). The functional response type II was observed for both phytoseiids when fed on eggs of A. cocois, suggesting effectivity for the control at low pest population density (de Alfaia et al. 2018).

Some phytoseiid mites (Amblydromalus limonicus (Garmam \& McGregor), Amblyseius swirskii Athias-Henriot, and Euseius gallicus Kreiter \& Tixier) have been used against another species of the whitefly, Bemisia tabaci (Gennadius) (Hemiptera: Aleyrodidae) in several European countries and in North America (Nomikou et al. 2003; Hoogerbrugge et al. 2005; Knapp et al. 2013; Lee \& Zhang 2018). Thus, it is possible that some of the species that commonly occur on these trees, as $A$. largoensis and E. concordis, have the potential to be used in the control of A. cocois, as suggested by de Alfaia et al. (2018). The present study was designed to evaluate whether $A$. cocois eggs may support the development and reproduction of the phytoseiid mites E. concordis and A. largoensis.

Specimens of $A$. largoensis and $E$. concordis were collected directly from cashew leaves in the experimental area of the Universidade Federal do Ceará, Fortaleza-CE, Brazil (-34ㄴ 'S, $\left.-38^{\circ} 44^{\prime} \mathrm{W}\right)$. The predators were kept in rearing units similar to those described by de Alfaia et al. (2018), at $25 \pm$ $1{ }^{\circ} \mathrm{C}, \mathrm{RH}$ of $70 \pm 10 \%$, and a photoperiod of $12 \mathrm{~h}$. Both species of predators were fed with a mixture of Tetranychus urticae Koch (Acari: Tetranychidae) (supplied in fragments of Canavalia ensiformes L., each fragment contained approximately 100 individuals in different stages of development), honey, and castor pollen (Ricinus communis L). The food was replenished whenever necessary 
(avoiding contamination in the unit, for example, by the development of fungi) or every 2 days, whichever happened first.

The development and viability of predators were evaluated using $A$. cocois eggs as the exclusive source of food. The experiment was conducted under the same conditions of temperature, relative humidity, and photoperiod used for rearing the predatory mites. Initially, 100 adult females of each predator species were confined for 24 hours in new rearing units to obtain the eggs to be used to start the experiment. After the confinement period, these females were removed and returned to rearing units; only eggs with a maximum age of 24 hours remained in the rearing units. These units were observed every 12 hours for larvae detection. Detected larvae were immediately and carefully transferred and isolated in experimental units. The experimental units were built similarly to those used to rear the predators, but in smaller dimensions ( $3 \times 3 \mathrm{~cm}$ PVC plates). Aleurodicus cocois eggs were provided as food on leaves fragments, two fragments were provided per experimental unit. The food was replenished every 2 days until the emergence of the adults.

Immature individuals that reached adulthood when fed exclusively on A. cocois eggs were sexed. Females were paired with males from rearing units and fed daily with newly collected $A$. cocois eggs. Again two leaves fragments containing around 25 eggs each, were provided per experimental unit. The experimental units were inspected daily for oviposition and mortality of adults. In case of a male death, it was replaced by another male from the rearing units. Thus, the periods of pre-oviposition, oviposition and post-oviposition, the number of eggs per female and longevity were determined. Due to the reduced number of $E$. concordis females that performed oviposition, the population parameters were only estimated for A. largoensis. Population parameters were estimated using a fertility life table. The fertility life table was elaborated, according to Silveira Neto et al. (1976), using data on age (x), mean oviposition (mx) and survival (lx). The following parameters were estimated: net reproduction rate: $\mathrm{R}_{0}=\Sigma 1 \mathrm{xmx}$, mean generation time: $\mathrm{T}=\Sigma \mathrm{x} l \mathrm{xmx} /$ $\Sigma \mid x m x$, intrinsic population growth rate: $\mathrm{r}_{\mathrm{m}}=\operatorname{Ln}\left(\mathrm{R}_{0}\right) / \mathrm{r}_{\mathrm{m}}$, finite population growth rate; $\lambda=e^{r_{m}}$, and time for the population to double in number: $\mathrm{TD}=\mathrm{Ln}\left(\mathrm{R}_{0}\right) / \mathrm{r}_{\mathrm{m}}$.

Aleurodicus cocois eggs allowed the survival and development of immature forms to reach adulthood in E. concordis and A. largoensis (Table 1). The high survival rate observed in immatures of both species suggests that the number of eggs offered per immature was adequate. Eveleigh \& Chant (1982) demonstrated that dietary restrictions (reduced food supply) during the development of immature phytoseiids result in high mortality. Individuals of $A$. largoensis reached the adult phase in a shorter time than E. concordis (Table 1), suggesting differences in food requirement or differences in the ability to convert food into energy. The results obtained in the development time of both predators are similar to those reported in other studies evaluating phytophagous mites as the exclusive source of food (Rodriguez \& Ramos 2004; Galvão et al. 2007; Carrillo et al. 2010; Marques et al. 2015).

Both E. concordis and A. largoensis presented reduced reproductive potential when fed on $A$. cocois eggs (Table 2). These results supports the hypothesis raised by de Alfaia et al. (2018) that $A$. cocois eggs may not represent a better dietary resource for $E$. concordis. In that study, the absence of a pattern of variation of predator oviposition according to prey densities was observed for both $E$. concordis and A. largoensis when fed on A. cocois eggs.

For Euseius concordis only 2 out of 29 females performed oviposition. Reduced reproductive potential have been reported in E. concordis fed on Tetranychus evansi (Acari: Tetranychidae) (Moraes \& Lima 1983), on a mixture of T. evansi + Aculops lycopersici (Acari: Eriophyidae) (Massee) (Moraes \& Lima 1983) and on different species of Astigmata (Barbosa \& Moraes 2015). According to Sabelis $(1985 \mathrm{a}, \mathrm{b})$, the production of eggs by phytoseiids requires a lot from their feeding, not only because of the number of eggs produced but also because of the amount of food invested per egg. Additionally, Gotoh \& Tsuschiya (2008) report that in the presence of stress 
conditions and low food quantity and/or quality, mites can direct resources that would be destined to oviposition to extend their longevity. This fact may explain not only the lack of oviposition in most $E$. concordis females but also the numerically superior longevity of these females compared to $A$. largoensis females (Table 2).

Contrary to what was observed in E. concordis, most A. largoensis females performed oviposition (Table 2), which suggests distinct nutritional requirements between these two predators. Despite the oviposition, the reproductive parameters observed in A. largoensis indicate that the tested diet (A. cocois eggs) does not represent one of the best foods for this predator-in the line as those suggested by de Alfaia et al. (2018). The comparison of the results obtained in this study with those reported in studies conducted under similar conditions, and where A. largoensis was fed exclusively on mites, shows superior reproductive parameters (female longevity, oviposition, and net reproduction rate) in those studies in A. largoensis fed on Polyphagotarsonemus latus (Banks) (Acari: Tarsonemidae) (Rodriguez \& Ramos 2004), Aceria guerreronis Keifer (Acari: Eriophyidae) (Galvão et al. 2007), Tetranychus gloveri Banks (Acari: Tetranychidae), and Raoiella indica Hisrt (Acari: Tenuipalpidae) (Carrillo et al. 2010).

TABLE 1. Duration of immature stages (mean $\pm \mathrm{SE}$ ) and survivorship (mean $\pm \mathrm{SE}$ ) of A. largoensis and $E$. concordis fed exclusively on $A$. cocois eggs.

\begin{tabular}{lllll}
\hline & \multicolumn{2}{l}{ A. largoensis (37) } & & E. concordis (39) \\
\cline { 2 - 5 } & Duration (days) & Survival (\%) & Duration (days) & Survival (\%) \\
\hline Egg & $2.0 \pm 0.08$ & 100 & $2.1 \pm 0.05$ & 100 \\
Larva & $0.93 \pm 0.06$ & $97.3 \pm 2.63$ & $1.5 \pm 0.09$ & 100 \\
Protonymph & $1.43 \pm 0.07$ & 100 & $1.85 \pm 0.08$ & $89.7 \pm 4.92$ \\
Deutonymph & $1.54 \pm 0.09$ & $94.4 \pm 3.71$ & $1.70 \pm 0.06$ & $97.1 \pm 2.85$ \\
Egg-Adult & $5.9 \pm 0.13$ & $91.9 \pm 4.43$ & $7.2 \pm 0.11$ & $87.2 \pm 5.42$ \\
\hline
\end{tabular}

TABLE 2. Biological parameters (mean \pm SE or mean followed by $95 \%$ confidence intervals for life table parameters) of $A$. largoensis and $E$. concordis fed exclusively on $A$. cocois eggs.

\begin{tabular}{lll}
\hline & A. largoensis & E. concordis \\
\hline Evaluated females & 23 & 29 \\
Females that oviposited & 20 & 2 \\
Pre-oviposition time (days) & $2.6 \pm 0.14$ & $3.5 \pm 0.50$ \\
Oviposition time (days) & $2.9 \pm 0.52$ & $3.5 \pm 2.50$ \\
Longevity (days) & $8.8 \pm 0.77$ & $10.4 \pm 0.65$ \\
Maximum survival time (days) & 18 & 21 \\
Oviposition (eggs per female) & $3.1 \pm 0.60$ & $0.2 \pm 01$ \\
Net reproduction rate (females/female) & $1.5(0.96-2.02)$ & - \\
Intrinsic growth rate (females/female/day) & $0.04(0.007-0.08)$ & - \\
Finite population growth rate & $1.04(1.00-1.08)$ & - \\
Generation time (days) & $9.4(8.74-10.11)$ & - \\
Time for population to double in number & $12.6(2.97-28.15)$ & -
\end{tabular}

The apparent difference in the nutritional requirements of $A$. largoensis and E. concordis can have important consequences at the population level. It is possible, for example in the field, that $E$. concordis adults would not use $A$. cocois eggs as food, and thus, avoid direct competition with $A$. 
largoensis. It is important to highlight that both evaluated predator species are commonly found in cashew trees, regardless of the presence of $A$. cocois. Therefore, as long as it is possible for predators to use $A$. cocois eggs for their development or as food supplementation in the adult phase, these predators may contribute to the control of this pest. Conservative strategies aiming not only at the permanence of predators but also their increments should be explored. These strategies, in particular if implemented before the colonization of plants by A. cocois, could potentially prevent their establishment.

\section{ACKNOWLEDGMENTS}

This research was supported by grants of the CNPq [Conselho Nacional de Desenvolvimento Científico e Tecnológico, D.B. Lima - PDJ - Proc. 150055/2017-0; J.W.S. Melo - PQ - 306372/20177] from the Brazilian government.

\section{REFERENCES}

Agrofit - Sistema de Agrotóxicos Fitossanitários - Ministério da Agricultura, Pecuária e Abastecimento - Coordenação Geral de Agrotóxicos e Afins/DFIA/DAS (2018). Available from: http://agrofit.agricultura.gov.br/agrofit_cons/principal_agrofit_cons (acessed 11 january 2018).

de Alfaia, J.P., Melo L.L., Monteiro, N.V., Lima, D.B. \& Melo, J.W.S. (2018) Functional response of the predaceous mites Amblyseius largoensis and Euseius concordis when feeding on eggs of the cashew tree giant whitefly Aleurodicus cocois. Systematic \& Applied Acarology, 23(8), 1559-1566. https://doi.org/10.11158/saa.23.8.6

Barbosa, M.F. \& Moraes, G.J. (2015) Evaluation of astigmatid mites as factitious food for rearing four predaceous phytoseiid mites (Acari: Astigmatina; Phytoseiidae). Biological Control, 91, 22-26. https://doi.org/10.1016/j.biocontrol.2015.06.010

Bleicher, E. \& Melo, Q.M.S. (1996) Artrópodes associados ao cajueiro no Brasil. 2a.ed. Fortaleza, Empresa Brasileira de Pesquisa Agropecuária / CNPAT, Documentos 9, 35 pp.

Byrne, D.N. \& Bellows Jr, T.S. (1991) Whitefly biology. Annual Review of Entomology, 36, 431-457. https://doi.org/10.1146/annurev.en.36.010191.002243

Byrne, D.N., Bellows, T.S. \& Parrella, M.P. (1990) Whiteflies in agricultural system. In: Gerling, D. (Ed.) Whiteflies: their bionomic, pest status and management. Andover, Hants, Intercept, pp. 227-261.

Carrillo, D., Peña, J.E., Hoy, M.A. \& Frank, J.H. (2010) Development and reproduction of Amblyseius largoensis (Acari: Phytoseiidae) feeding on pollen, Raoiella indica (Acari: Tenuipalpidae), and other microarthropods inhabiting coconuts in Florida, USA. Experimental and Applied Acarology, 52, 119-129. https://doi.org/10.1007/s10493-010-9360-1

Evans, G.A. (2007) Host plant list of the whiteflies (Aleyrodidae) of the world. USDA. Animal Plant Health Inspection Service (APHIS), pp. 1-290.89

Eveleigh, E.S. \& Chant, D.A. (1982) Experimental studies on acarine predator-prey interactions: the effects of predator density on immature survival, adult fecundity and emigration rates, and the numerical response to prey density (Acarina: Phytoseiidae). Canadian Journal of Zoology, 60, 630-638. https://doi.org/10.1139/z82-092

Galvão, A.S, Gondim, M.G.C., Moraes, G.J. \& Oliveira, J.V. (2007) Biology of Amblyseius largoensis (Muma) (Acari: Phytoseiidae), a potential predator of Aceria guerreronis Keifer (Acari: Eriophyidae) on coconut trees. Neotropical Entomology, 36, 465-470. http://dx.doi.org/10.1590/S1519-566X2007000300016

Gotoh, T. \& Tsuchiya, A. (2008) Food scarcity reduces female longevity of Neoseiulus californicus (Acari: Phytoseiidae). Experimental and Applied Acarology, 47, 119-129. https://doi.org/10.1007/s10493-008-9215-1

Hoogerbrugge, H., Calvo, J., van Houten, Y., Belda, J.E. \& Bolckmans, K. (2005) Biological control of the tobacco whitefly Bemisia tabaci with the predatory mite Amblyseius swirskii in sweet pepper crops. Inter- 
national Organisation for Biological and Integrated Control/wprs Bulletin, 28, 119-122.

Knapp, M., Van Houten, Y., Hoogerbrugge, H. \& Bolckmans, K. (2013) Amblydromalus limonicus (Acari: Phytoseiidae) as a biocontrol agent: literature review and new findings. Acarologia, 53, 191-202. https://doi.org/10.1051/acarologia/20132088

Lee, M.H. \& Zhang, Z.Q. (2018) Assessing the augmentation of Amblydromalus limonicus with the supplementation of pollen, thread, and substrates to combat greenhouse whitefly populations. Scientific Reports, $8,12189$. https://doi.org/10.1038/s41598-018-30018-3

Lima, D.B. \& Gondim Jr, M.G.C. (2008) Diversidade de ácaros em Anacardium occidentale (L.) no campus da Universidade Federal Rural De Pernambuco. In: XXII Congresso Brasileiro de Entomologia, Uberlândia.

Marques, C.C., Oliveira, C.H.C.M., Oliveira, C.R.L.F.O.S., Matioli, A.L. \& Lima Neto, I.F.A (2015) Biologia e tabela de vida do ácaro predador Euseius concordis (CHANT, 1959) (Acari: Phytoseiidae) em pinhãomanso. Revista Caatinga, 28, 249-255.

Martin, J.H. (1987) An identification guide to commom whitefly pest species of the world (Homoptera: Aleyrodidade). International Journal of Pest Management, 33, 298-322. https://doi.org/10.1080/09670878709371174

Melo, Q.M.S. \& Bleicher, E. (2002) Identificação e manejo das principais pragas do cajueiro. Caju fitosanidade. Brasília, DF: Empresa Brasileira de Pesquisa Agropecuária/ Agroindústria Tropical, pp. 9-34.

Mesquita, A.L.M. \& Braga Sobrinho, R. (2013) Pragas do cajueiro. In: Araújo, J.P.P. de (Eds.), Agronegócio caju: práticas e inovações. Brasília, DF: Empresa Brasileira de Pesquisa Agropecuária, pp. 195-215.

Monteiro, N.V., de Alfaia, J.P., Barros, M.E.N., Lima, D.B. \& Melo, J.W.S. (2017) Levantamento de ácaros fitoseídeos em plantas de Anacardium occidentale. Encontros Universitários. Universidade Federal do Ceará, 2, 3688 pp.

Moraes, G.J. \& Lima, H.C. (1983) Biology of Euseius concordis (Chant) (Acarina: Phytoseiidae), a predador of the tomato Russet Mite. Acarologia, 24, 251-255.

Nomikou, M., Janssen, A. \& Sabelis, M.W. (2003) Phytoseiid predator of whitefly feeds on plant tissue. Experimental \& Applied Acarology, 3, 27-36. https://doi.org/10.1023/B:APPA.0000005150.33813.04

Pessoa, P.F.A.P, Mattos, A.L.A., Leite, L.A.S., Cabral, J.E.O. \& Pimental, C.R.M. (2015) Economia. In: Araújo, J.P.P. (Ed.) Caju: o produtor pergunta, a Embrapa responde. Embrapa, Brasília, pp. 239-249.

Rodriguez, H. \& Ramos, M. (2004) Biology and feeding behavior of Amblyseius largoensis (Muma) Acari: Phytoseiidae) on Polyphagotarsonemus latus (Banks) (Acari: Tarsonemidae). Revista de Protección Vegetal, 19,73-79.

Sabelis, M.W. (1985a) Life History: Development. In: Helle, W. \& Sabelis, M.W. (Eds.) Spider mites: their biology, natural enemies and control. Amsterdam, Elsevier, pp. 43-53.

Sabelis, M.W. (1985b) Life History: Reproduction. In: Helle, W. \& Sabelis, M.W. (Eds.) Spider mites: their biology, natural enemies and control. Amsterdam, Elsevier, pp. 73-82.

Silveira Neto, S., Nakano, O., Barbin, D. \& Villa Nova, N.A. (1976) Manual de ecologia dos insetos. Piracicaba: Ceres, 419 pp.

Submitted: 21 Jul. 2018; accepted by Rostislav Zemek: 3 Oct. 2018; published: 5 Nov. 2018 